\title{
Critical metal enrichment in laterites
} from Chile

\author{
JOSE MARÍA GONZÁLEZ-JIMÉNEZ ${ }^{1}$, CRISTINA \\ VILLANOVA-DE-BENAVENT ${ }^{2}$, JOAQUIN ANTONIO \\ PROENZA $^{2}$, LUIS MONASTERIO-GUILLOT ${ }^{3}$ AND LINDA \\ DANIELE $^{4}$ \\ ${ }^{1}$ University of Granada Q1818002F \\ ${ }^{2}$ Universitat de Barcelona \\ ${ }^{3}$ Universidad de Granada \\ ${ }^{4}$ Universidad de Chile \\ Presenting Author: jmgonzj@ugr.es
}

The critical metals (CM) are a group of strategic elements used in advanced technologies, including the platinum-group elements (PGE: Os, Ir, Ru, Rh, Pt and Pd), the rare earth elements (REE: lanthanides, Sc and Y) and other metals like Co, and $\mathrm{Sb}$.

The PGE are hosted by a variety of different mineral deposits although the majority of the resources within our database are magmatic deposits where the PGE have been concentrated as a result of igneous processes. The REE are usually targeted in alkaline-carbonatite igneous rocks and granitic pegmatites. Extraction and concentration of minerals endowed with these critical metals, and metallurgical processing to separate the various critical metals can be difficult and expensive in these types of deposits, while the beneficiation for each deposit may be unique. In contrast to these types primary deposits, $\mathrm{Ni}$ laterites, formed during intense weathering of ultramafic rocks under tropical or sub-tropical (i.e., hot and humid) climate conditions, are considered worthy targets for CM exploration.

In south-cetnral Chile, Ni-lateriric soils originated at expenses of ultramafic ophiolitic rocks are known since time ago and interpeted to have been formed in a cold regime. However, they have not been explored yet for critical metals. In this comunication we show a significant secondary enrichment in a wide range of critical metals (from few ppb up to hundreds ppm even on early to intermediate stages of weathering of the ultramafic rock, and that such enrichment is not only restricted to tropical latitude as currently thought. Our result indicate that $\mathrm{Ni}$ lateritic soils originated in cold climates can be considered a potential source for critical metals. 